\title{
ОСОБЛИВОСТІ РЕМОДЕЛЮВАННЯ СТРУКТУР СЛИЗОВОЇ ОБОЛОНКИ ШЛУНКА ПІСЛЯ РІЗНИХ МЕТОДІВ ХІРУРГІЧНОГО ЛІКУВАННЯ ВИРАЗКОВОЇ ХВОРОБИ ШЛУНКА У ВІДДАЛЕНОМУ ПЕРІОДІ
}

А. Д. Беденюк

\author{
Тернопімьський державний медичний університет імені І. Я. Горбачевського
}

\begin{abstract}
Проведено морфометричні дослідження стінок оперованого шлунка після різних методів хірургічного лікування виразкової хвороби цього органа. Доведено, що у віддаленому періоді структура стінки оперованого шлунка мала тенденцію до регенерації. Найоптимальніші зміни виявлені після органощадного методу оперативного лікування селективної проксимальної ваготомії з прицільною резекцією ішемізованого сегмента шлунка за Л. Я. Ковальчуком.
\end{abstract}

Ключові слова: виразкова хвороба шлунка, морфометрія, ремоделювання, хірургічне лікування.

\section{ОСОБЕННОСТИ РЕМОДЕЛИРОВАНИЯ СТРУКТУР СЛИЗИСТОЙ ОБОЛОЧКИ ЖЕЛУДКА ПОСЛЕ РАЗНЫХ МЕТОДОВ ХИРУРГИЧЕСКОГО ЛЕЧЕНИЯ ЯЗВЕННОЙ БОЛЕЗНИ ЖЕЛУДКА В ОТДАЛЕННОМ ПЕРИОДЕ}

\begin{abstract}
А. Д. Беденюк
Тернопольский государственный медицинский университет имени И. Я. Горбачевского

Произведено морфометрическое исследование стенок оперированного желудка после различных методов хирургического лечения язвенной болезни желудка. Доказано, что в отдаленном периоде структура стенки оперированного желудка имела тенденцию к регенерации. Наиболее оптимальные изменения виявлены после органощадящего метода оперативного лечения - селективной проксимальной ваготомии с прицельной резекцией ишемизированного сегмента желудка за Л. Я. Ковальчуком.
\end{abstract}

\begin{abstract}
Ключевые слова: язвенная болезнь желудка, ремоделирование, хирургическое лечение.
\section{FEATURES OF GASTRIC MUCOSA STRUCTURES REMODELING AFTER DIFFERENT METHODS OF SURGICAL TREATMENT OF PEPTIC ULCER IN THE REMOTE PERIOD}

\author{
A. D. Bedenyuk \\ Ternopii State Medical University by I. Ya. Horbachevsky
}

\begin{abstract}
A morphometric study of operated stomach walls after different methods of surgical treatment of gastric ulcer was performed. It was shown that in the remote period operated stomach wall structure had a tendency to regenerate. The most optimal changes were detected after organsparing method of surgical treatment - selective proximal vagotomy with sighting resection of ischemic segment of the stomach by L. Ya. Kovalchuk.
\end{abstract}

Key words: stomach ulcer, morphometry, remodeling, surgical treatment.

Вступ. Виразкова хвороба шлунка (ВХШ) і дванадцятипалої кишки (ДПК) зустрічається у $10 \%$ населення і характеризується високою частотою загострень та ускладнень, в тому числі і кровотечами $[6,7,9,10]$. Так, в Україні щороку відмічається більше 25 тис. госпіталізацій 3 приводу кровотеч на грунті виразкової хвороби шлунка і ДПК, а частота патології складає 7 випадків на 1 тис. населення $[4,5,8]$. (C) А. Д. Беденюк
Важливе значення мають етіологічні і патогенетичні фактори, що можуть слугувати прогностичними ознаками типологічної характеристики окремих форм виразкової хвороби (BX), присутні при прояві захворювання, зберігаються в період ремісії та можуть виявитися причиною нового рецидиву захворювання [3, 12].

За допомогою загальноклінічних, ендоскопічних, морфологічних і мікробіологічних досліджень підтвер- 
джується етіопатогенетична і клінічна неоднорідність різних форм виразок шлунка, об'єднаних єдиним морфологічним субстратом - виразковим дефектом слизової оболонки і супутнім активним гастродуоденітом, іноді й рефлюкс-езофагітом [11].

Мета. Вивчити особливості ремоделювання структур слизової оболонки шлунка після різних методів хірургічного лікування виразкової хвороби цього органа у віддаленому періоді.

Матеріали та методи дослідження. Морфологічними методами досліджено стінку шлунка з виразковою хворобою у 15 пацієнтів, а також після операції за методом Більрот-I у 12 пацієнтів, Більрот-II - у 10 хворих та СПВ-ПРІСШ - у 15 пацієнтів. Контролем служили дослідження стінок шлунків 12-ти померлих осіб, які не хворіли на патологію шлунково-кишкового тракту. Для вивчення особливостей структурних змін у стінці шлунка після хірургічного лікування, застосовували гістологічні, морфологічні та морфометричні методи дослідження. Матеріал отримували під час ендоскопічного дослідження шляхом біопсії та інтраопераційно після висічення ділянок стінки шлунка.
Для морфологічного дослідження матеріал фіксували в $10 \%$ нейтральному розчині формаліну, рідинах Карнуа, Ценкера, $96^{\circ}$ етиловому спирті, і після відповідного проведення через спирти зростаючої концентрації заливали в парафін. Мікротомні зрізи фарбували гематоксиліном та еозином, пікрофусцином за Ван-Гізон, Маллорі, Вейгертом.

Гістологічні мікропрепарати із стінки шлунка вивчали світлооптично та морфометрично. Визначали товщину слизової оболонки, підслизової основи, м'язової оболонки стінки шлунка, відносні об' єми епітелюцитів, капілярів, пошкоджених епітеліоцитів, висоту покривних епітеліоцитів, діаметр їхніх ядер. Вираховували також слизово-підслизовий (ICП) і підслизово-м'язовий (IMП) індекси та капілярно-епітеліальні і ядерноцитоплазматичні відношення $[1,2]$.

Результати досліджень й обговорення. Морфометричними методами встановлено, що різні методи хірургічного лікування виразкової хвороби приводили до структурних змін у стінці шлунка (табл. 1). Так, після резекції шлунка за Більрот-I товщина слизової оболонки зросла $3(524,70 \pm 5,40)$ до

Таблиця 1. Морфометричні параметри шлунка при хірургічних методах лікування виразкової хвороби цього органа $(\mathrm{M} \pm \mathrm{M})$

\begin{tabular}{|c|c|c|c|c|c|}
\hline \multirow[b]{2}{*}{ Показник } & \multicolumn{5}{|c|}{ Група спостереження } \\
\hline & Контрольна & $\begin{array}{l}\text { Виразкова } \\
\text { хвороба }\end{array}$ & Більрот-I & Більрот-ІІ & $\begin{array}{c}\text { СПВ+ } \\
\text { ПРІСШ }\end{array}$ \\
\hline $\begin{array}{l}\text { Товщина слизової } \\
\text { оболонки, мкм }\end{array}$ & $586,40 \pm 6,60$ & $\begin{array}{l}524,70 \pm \\
5,20 * * *\end{array}$ & $\begin{array}{c}538,20 \pm \\
5,40 * *\end{array}$ & $\begin{array}{c}531,80 \pm \\
5,40 * * \\
\end{array}$ & $557,10 \pm 5,70$ \\
\hline $\begin{array}{l}\text { Товщина підслизової } \\
\text { основи, мкм }\end{array}$ & $64,80 \pm 1,50$ & $68,60 \pm 1,50$ & $66,70 \pm 1,80$ & $67,50 \pm 1,50$ & $66,20 \pm 1,80$ \\
\hline $\begin{array}{l}\text { Товщина м'язової } \\
\text { оболонки, мкм }\end{array}$ & $609,70 \pm 7,20$ & $589,70 \pm 5,30^{*}$ & $597,50 \pm 5,10$ & $593,10 \pm 5,40$ & $602,30 \pm 5,40$ \\
\hline $\begin{array}{l}\text { Товщина серозної } \\
\text { оболонки, мкм }\end{array}$ & $64,30 \pm 1,50$ & $63,70 \pm 1,40$ & $63,90 \pm 1,20$ & $63,80 \pm 1,40$ & $64,10 \pm 1,50$ \\
\hline Індекс слизово-підслизовий & $0,110 \pm 0,004$ & $0,130 \pm 0,003 *$ & $0,124 \pm 0,003 *$ & $0,127 \pm 0,004 *$ & $0,119 \pm 0,003$ \\
\hline Індекс підслизово-м'язовий & $0,106 \pm 0,003$ & $0,116 \pm 0,002 *$ & $0,112 \pm 0,003$ & $0,114 \pm 0,003$ & $0,109 \pm 0,004$ \\
\hline $\begin{array}{l}\text { Відносний об'єм } \\
\text { епітеліоцитів, \% }\end{array}$ & $\begin{array}{c}0,0960 \pm \\
0,0020\end{array}$ & $\begin{array}{l}0,0890 \pm \\
0,0021^{*}\end{array}$ & $\begin{array}{c}0,0910 \pm \\
0,0018\end{array}$ & $\begin{array}{l}0,0902 \pm \\
0,0018^{*}\end{array}$ & $\begin{array}{c}0,0920 \pm \\
0,0021\end{array}$ \\
\hline $\begin{array}{l}\text { Відносний об'єм капілярів, } \\
\%\end{array}$ & $\begin{array}{c}0,00280 \pm \\
0,00005\end{array}$ & $\begin{array}{l}0,00238 \pm \\
0,00004^{*}\end{array}$ & $\begin{array}{c}0,00250 \pm \\
0,00003 * *\end{array}$ & $\begin{array}{c}0,00243 \pm \\
0,00004 * *\end{array}$ & $\begin{array}{c}0,00258 \pm \\
0,00003 * *\end{array}$ \\
\hline $\begin{array}{l}\text { Капілярно-епітеліальне } \\
\text { відношення }\end{array}$ & $\begin{array}{c}0,0290 \pm \\
0,0004\end{array}$ & $\begin{array}{c}0,0267 \pm \\
0,003 * * *\end{array}$ & $\begin{array}{c}0,02750 \pm \\
0,0004^{*}\end{array}$ & $\begin{array}{l}0,0270 \pm \\
0,0004 * \\
\end{array}$ & $\begin{array}{c}0,0780 \pm \\
0,0005 \\
\end{array}$ \\
\hline $\begin{array}{l}\text { Висота покривних } \\
\text { епітеліоцитів, мкм }\end{array}$ & $25,30 \pm 0,51$ & $20,50 \pm 0,42 * * *$ & $22,60 \pm 0,45^{*}$ & $21,40 \pm 0,42 * *$ & $23,70 \pm 0,45^{*}$ \\
\hline $\begin{array}{l}\text { Діаметр ядер епітеліоцитів, } \\
\text { мкм }\end{array}$ & $6,20 \pm 0,12$ & $5,18 \pm 0,09 * * *$ & $5,67 \pm 0,12 *$ & $5,38 \pm 0,09 *$ & $5,90 \pm 0,12$ \\
\hline $\begin{array}{l}\text { Ядерно-цитоплазматичне } \\
\text { відношення }\end{array}$ & $\begin{array}{c}0,0600 \pm \\
0,0012\end{array}$ & $\begin{array}{l}0,0640 \pm \\
0,0012 *\end{array}$ & $\begin{array}{l}0,0630 \pm \\
0,0009^{*}\end{array}$ & $\begin{array}{l}0,0634 \pm \\
0,0012 *\end{array}$ & $\begin{array}{c}0,0620 \pm \\
0,0012\end{array}$ \\
\hline $\begin{array}{l}\text { Відносний об'єм пош- } \\
\text { коджених епітеліоцитів, \% }\end{array}$ & $1,90 \pm 0,03$ & $51,4 \pm 1,2 * * *$ & $36,70 \pm, 87 * * *$ & $45,6 \pm 1,2 * * *$ & $24,50 \pm 0,51 * * *$ \\
\hline
\end{tabular}

Примітка: $1 .{ }^{*}-p<0,05 ; 2 .^{* *}-p<0,01 ; 3 .{ }^{* *}-p<0,001$. 
$(538,20 \pm 5,40)$ мкм, тобто на 2,57 \%. При цьому наведені морфометричні параметри між собою статистично достовірно не відрізнялися $(\mathrm{p}>0,05)$. Після резекції шлунка за Більрот-ІІ товщина слизової оболонки досліджуваного органа дорівнювала $(531,80 \pm 5,40)$ мкм. Ця цифрова величина перевищувала аналогіч-

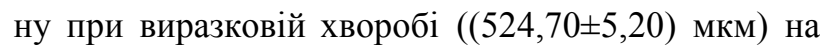
1,35 \% і була меншою за аналогічну контрольну величину $((586,40 \pm 6,60)$ мкм) на 9,3\% й суттєво $(\mathrm{p}<0,01)$ не відрізнялася від останньої.

Після СПВ+ПРІСШ товщина слизової оболонки ураженого шлунка збільшилась $3(524,70 \pm 5,20)$ мкм до $(557,10 \pm 5,70)$ мкм, тобто майже на 6,2 \%. Варто вказати, що наведені цифрові величини статистично достовірно $(\mathrm{p}<0,01)$ відрізняються між собою. Останній морфометричний параметр виявився меншим на 5,0 \% за аналогічний контрольний - $(586,40 \pm$ $6,60)$ мкм й істотно $(\mathrm{p}<0,05)$ відрізнявся від нього.

Морфометричними вимірами також встановлено, що товщина підслизової основи ураженого шлунка після застосування вказаних методів операцій зменшувалася. Так, після резекції шлунка за Більрот-I даний морфометричний параметр знизився 3 $(68,60 \pm 1,50)$ до $(66,70 \pm 1,80)$ мкм, тобто на $2,8 \%$, після резекції вказаного органа за Більрот-II на 1,7 \%, а після СПВ+ПРІСШ - на 3,5\%.

Товщина м'язової оболонки ураженого шлунка після використання різних хірургічних методів лікування виразкової хвороби мала тенденцію до зростання. Так, після проведення операції за Більрот-I вона збільшилась $3(589,70 \pm 5,30)$ до $(597,50 \pm 5,10)$ мкм, тобто на $1,3 \%$, після резекції шлунка за Більрот-ІІ - на 0,6 \%, а після СПВ+ПРІСШ - на 2,1%. Варто при цьому зазначити, що наведені цифрові величини не досягали аналогічної контрольної $(609,70 \pm 7,20)$ мкм і статистично достовірно від неї ( $>>0,05)$ не відрізнялися.

Товщина серозної оболонки ураженого шлунка після застосування перерахованих методів хірургічного лікування виразкової хвороби зростала. Так, після резекції шлунка за Більрот-І даний морфометричний параметр зріс на 0,3 \%, після Більрот-II - на 0,16 \%, а після СПВ+ПРІСШ - на 0,62\%.

Слизово-підслизовий індекс у досліджуваних патологічних умовах, коригованих різними хірургічними методами, мав тенденцію до зменшення. Так, після корекції виразкової хвороби за Більрот-I він знизився $3(0,130 \pm 0,003)$ до $(0,124 \pm 0,003)$, тобто на $4,6 \%$, після Більрот-II - на $2,3 \%$, а після СПВ+ПРІСШ - на $8,46 \%$.

Підслизово-м'язовий індекс ураженого шлунка після застосування різних методів хірургічного ліку- вання виразкової хвороби мав також тенденцію до зниження. Так, після резекції шлунка за Більрот-I вказаний морфометричний параметр знизився 3 $(0,116 \pm 0,002)$ до $(0,112 \pm 0,003)$, тобто на $3,4 \%$, після резекції досліджуваного органа за Більрот-II - на 1,7 \%, а після СПВ+ПРІСШ на 6,0 \%. Варто вказати, що в останній групі спостережень вказаний морфометричний показник $(0,109 \pm 0,004)$ статистично достовірно не відрізнявся $(\mathrm{p}>0,05)$ від аналогічного контрольного $(0,106 \pm 0,003)$.

Відносний об'єм епітеліоцитів слизової оболонки шлунка після використання різних методів хірургічного лікування виразкової хвороби зростав. Так, після резекції шлунка за Більрот-І даний морфометричний показник збільшився $3(0,089 \pm 0,0021)$ до $(0,0910 \pm 0,0018) \%$, тобто на 2,25 \%, після резекції за Більрот-II - на 1,35 \%, а після СПВ+ПРІСШ - на 3,4\%. Статистично вірогідна різниця при цьому знайдена між досліджуваним контрольним параметром $((0,0902 \pm 0,0020) \%)$ та таким же показником після резекції шлунка за Більрот-II (0,0902 $\pm 0,0018, \mathrm{p}<0,05)$.

Проведеними морфометричними дослідженнями встановлено, що різні хірургічні методи лікування виразкової хвороби неоднаково впливали на стан мікрогемоциркуляторного русла шлунка. Так, після резекції шлунка за Більрот-І відносний об' єм капілярів ураженого досліджуваного органа зріс з $(0,00238 \pm 0,00004) \%$ до $(0,00250 \pm 0,00003) \%$. Наведені цифрові величини статистично достовірно відрізнялися між собою ( $<<0,05)$. При цьому остання цифрова величина перевищувала попередню на 5,0%. Після резекції шлунка за Більрот-II досліджуваний морфометричний параметр дорівнював $(0,00243 \pm 0,00004) \%$. Ця цифрова величина виявилась меншою на 13,2 \% за аналогічну контрольну $(0,00280 \pm 0,00005) \%$ і перевищувала відносний об'єм капілярів на 2,1 \% ураженого шлунка $(0,00238 \pm 0,00004) \%$. Після проведення СПВ+ПРІСШ дана морфометрична величина у шлунку дорівнювала $(0,00258 \pm 0,00003) \%$. Даний морфометричний параметр статистично достовірно $(\mathrm{p}<0,05)$ відрізнявся від такого ж контрольного $(0,00280 \pm 0,00005) \%$ і був меншим за нього на 7,8 \%. В той же час досліджуваний морфометричний параметр перевищував аналогічний ураженого шлунка на 8,4%. Можна вважати, що після проведення хірургічної корекції виразкової хвороби кровопостачання шлунка покращувалося. Сказане також підтверджувалось динамікою капілярно-епітеліальних відношень. Так, після резекції шлунка за Більрот-І капілярно-епітеліальні відношення зросли майже на 3,0 \%, після резекції шлунка за Більрот-II - на 1,12 \%, а після СПВ+ПРІСШ - на 4,9\%. 
Застосування хірургічних методів лікування виразкової хвороби приводило також до покращення структури покривних епітеліоцитів шлунка, що підтверджувалось морфометричними вимірами. Так, після резекції шлунка за Більрот-І висота покривних епітеліоцитів шлунка зростала $3(20,50 \pm 0,42)$ до $(22,60 \pm 0,45)$ мкм, тобто на 10,2 \%. Варто також вказати, що між наведеними цифровими величинами існувала статистично достовірна $(\mathrm{p}<0,05)$ різниця.

В цій групі спостережень діаметр ядер епітеліоцитів досліджуваного органа зріс $3(5,18 \pm 0,09)$ до $(5,67 \pm 0,12)$ мкм, тобто на 9,45 \%. При визначенні різниці між наведеними цифровими величинами виявлено, що коефіцієнт Стьюдента дорівнював 3,66, тобто досліджувані морфометричні параметри між собою статистично достовірно $(\mathrm{p}<0,01)$ відрізнялися. Ядерно-цитоплазматичні відношення у вказаних клітинах при цьому дорівнювали $(0,0630 \pm 0,00009)$. Наведена цифрова величина суттєво відрізнялась $(\mathrm{p}<0,05)$ від аналогічної контрольної $(0,0600 \pm 0,0012)$ i свідчила про те, що після виконаної хірургічної корекції структурний клітинний гомеостаз залишався ще порушеним.

Після резекції шлунка за Більрот-II висота епітеліоцитів ураженого шлунка зросла з $(20,50 \pm 0,42)$ до $(21,40 \pm 0,42)$ мкм. Варто зазначити, що наведені цифрові величини між собою суттєво не відрізнялися ( $>0,05)$. При цьому останній морфометричний параметр перевищував попередній майже на 4,4 \%. Діаметр ядер досліджуваних клітин в даних умовах патології та іiї хірургічної корекції за Більрот-II зріс 3 $(5,18 \pm 0,09)$ до $(5,38 \pm 0,09)$ мкм. Між наведеними цифровими величинами не знайдено статистично достовірної ( $p>0,05)$ різниці. Водночас останній морфометричний параметр перевищував попередній на 3,86 \%. Ядерно-цитоплазматичні відношення у досліджуваних клітинах дорівнювали $(0,0634 \pm 0,0012)$. Ця цифрова величина статистично достовірно $(\mathrm{p}<0,05)$ відрізнялася від такої ж контрольної $(0,0600 \pm 0,0012)$. Після СПВ+ПРІСШ ядерно-цитоплазматичні відношення у епітеліоцитах досягали $(0,0620 \pm 0,0012)$ і перевищували аналогічну контрольну величину на

\section{Література.}

1. Автандилов Г. Г. Основы количественной патологической анатомии / Г. Г. Автандилов. - М. : Медицина, 2002. - 240 с. 2. Автандилов Г. Г. Медицинская морфометрия / Г. Г. Автандилов. - М. : Медицина, 1990. - 318 с.

3. Бутов М. А. Об этиологии и патогенезе язвенной болезни / М. А. Бутов // Экспериментальная и клиническая гастроэнтерология. - 2003. - $\mathrm{N}^{\circ}$ 5. - С. 5-9.
}

3,3 \%. При цьому, досліджуваний показник суттєво не відрізнявся від аналогічних контрольних ( $p>0,05)$.

Аналіз динаміки відносного об'єму пошкоджених епітеліоцитів показав, що після застосування різних хірургічних методів лікування ВХ шлунка він змінювався в сторону покращення. Так, після резекції шлунка за Більрот-І відносний об'єм пошкоджених епітеліоцитів зменшився $3(51,4 \pm 1,2)$ до $(36,70 \pm 0,87) \%$, тобто на 14,7 \%. Наведені цифрові величини між собою статистично достовірно відрізнялися $(\mathrm{p}<0,001)$. Після резекції шлунка за Більрот-II досліджуваний морфометричний параметр досягав $(45,6 \pm 1,2) \%$. Даний показник перевищував аналогічний контрольний у 24 рази і виявився меншим за такий же параметр в ураженому некорегованому шлунку на $5,8 \%$. Найменший відносний об'єм пошкоджених епітеліоцитів виявився після застосування СПВ+ПРІСШ. В даних умовах дослідження вказаний морфометричний показник дорівнював $(24,50 \pm 0,51) \%$. Наведений морфометричний параметр перевищував такий же контрольний майже у 12,9 раза і статистично достовірно $(\mathrm{p}<0,001)$ від нього відрізнявся. Необхідно вказати, що досліджуваний показник виявився також меншим за аналогічний параметр у некорегованому ураженому шлунку $((51,4 \pm 1,2) \%)$ на $26,9 \%$.

Висновки. 1. Після хірургічних методів лікування у всіх групах оперованих пацієнтів спостерігалася позитивна динаміка відновлення структур стінки шлунка.

2. Товщина слизової оболонки після резекцій шлунка за Більрот-І зросла на 2,57 \%, після Більрот-П - на 1,35 \%, а після СПВ+ПРІСШ за Л. Я. Ковальчуком - на 6,2 \%.

3. Об'єм пошкоджених епітеліоцитів зменшився після резекцій за Більрот-I - на 14,7 \%, після БільротII - на 5,8 \% та після СПВ+ПРІСШ за Л. Я. Ковальчуком - на 26,9 \% порівняно з аналогічним показником некорегованого ураженого шлунка.

4. Морфометричні дослідження показали, що 3 хірургічних методів лікування виразкової хвороби шлунка найоптимальнішим методом, що суттєво покращував структуру стінки шлунка, $\epsilon$ СПВ+ПРІСШ.

4. Вибір методу хірургічного лікування виразок дванадцятипалої кишки, ускладнених субкомпенсованим стенозом, з урахуванням морфофункціональних особливостей стінки шлунка / Л. Я. Ковальчук, А. Д. Беденюк, М. С. Гнатюк [та ін.] // ХХІІ з'їзд хірургів України, 2-5 червня 2010 р. : матеріали з'їзду. - Вінниця : ТзОВ «Нілан ЛТД», 2010. - Т. 1. - С. 209-210. 
5. Вибір методів хірургічного лікування гастродуоденальних виразок / Л. Я. Ковальчук, В. М. Полішук, М. М. Велігоцький [та ін.] - Тернопіль, Рівне : Вертекс, 1997. - 144 с. 6. До питання хірургічного лікування хворих на виразкову хворобу шлунка та дванадцятипалої кишки, ускладнену кровотечею / I. А. Тарабан, І. В. Приворотько, В. Г. Грома [та ін.] // Харківська хірургічна школа. -2008 . №21. - С. 68 72.

7. Логунов К. В. Патология желудочных язв / К. В. Логунов // Патологическая физиология и экспериментальная терапия. - 1997. - №> 4. - С. 37-39.

8. Оптимізація хірургічного лікування виразкової хвороби та їі ускладнень // І. А. Тарабан, В. Г. Грома, І. О. Дрозд, Д. В. Оклей // Харківська хірургічна школа. - 2010. - №2 1. С. $180-183$.
9. Федченко Ю. Г. Виразкова хвороба шлунка і дванадцятипалої кишки: епідеміологічні особливості захворюваності населення України / Ю. Г. Федченко // Проблеми медичної науки та освіти. - 2006. - $\mathrm{N}^{\circ}$ 1. - С. 48-50.

10. Федченко Ю. Г. Епідеміологічні особливості захворюваності і поширеності виразкової хвороби шлунка і дванадцятипалої кишки серед працездатного населення України / Ю. Г. Федченко // Вісник соціальної гігієни та організації охорони здоров'я. - 2005. - № 2. - С. 46-50.

11. Хвороби органів травлення / П. Я. Григор'єв, Є. М. Стародуб, Е. П. Яковенко [та ін.] - Тернопіль : Укрмедкнига, 2000. - С. 49-54.

12. Watanabe T. Patogenesis of gastric and duodenal ulcer in the elderly / T. Watanabe, T. Chiba // Nippon Rinsho. - 2002. Vol. 60, № 8. - P. 1515-1520. 